\title{
The scientific and personal imprint of Jordi Font, a serene oceanographer
}

\author{
Josep L. Pelegrí ${ }^{1}$, Carolina Gabarró ${ }^{1}$, Adriano Camps ${ }^{2}$ \\ 'Departament d'Oceanografia Física i Tecnològica, Institut de Ciencies del Mar, CSIC, Barcelona. \\ ${ }^{2}$ Departament de Teoria de la Senyal i Communicacions, Universitat Politècnica de Catalunya, \\ and Institut d'Estudis Espacials de Catalunya/CTE-UPC, Barcelona.
}

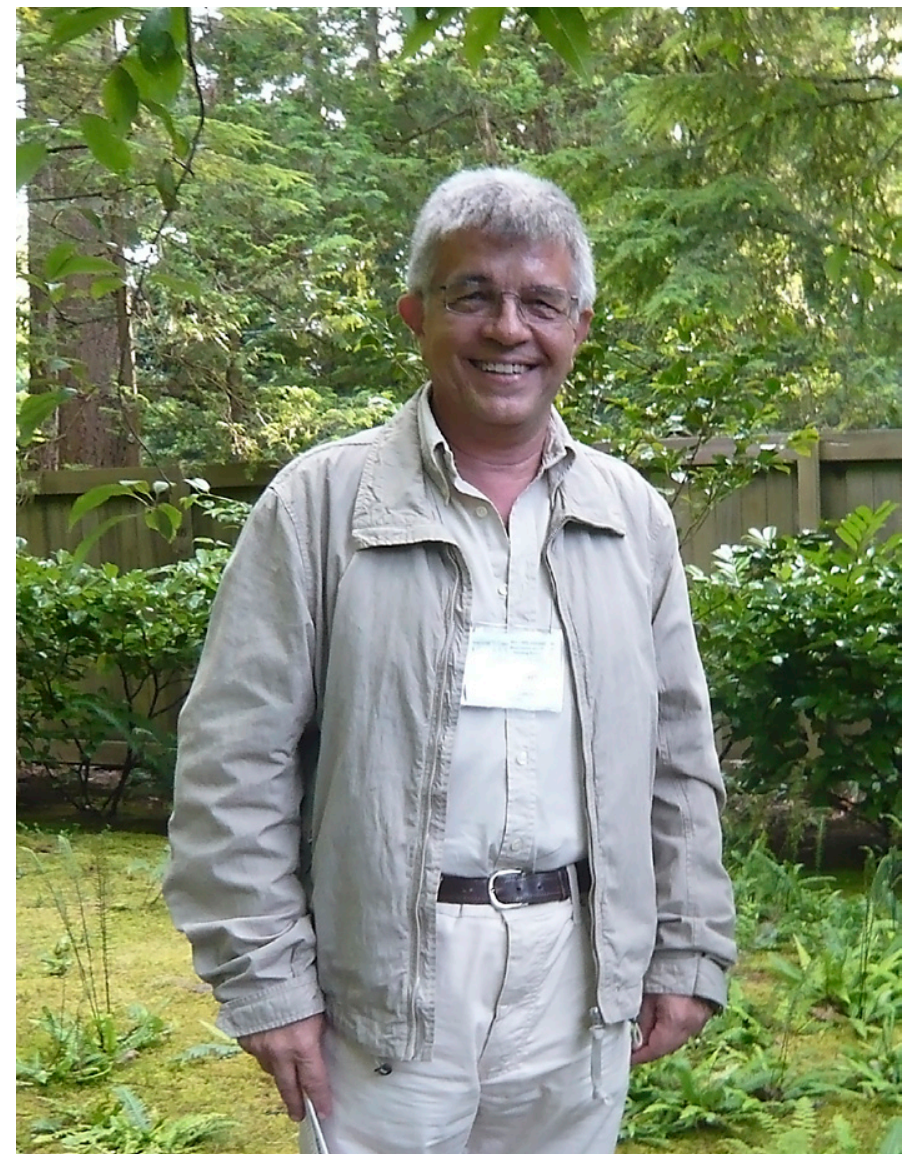

Physical oceanographers have been principal actors in Scandinavian research centres since the end of the 19 th century, and in other northern European countries and the United States since the 1920s. The study of the physical marine environment developed even further in these countries during the 1960 s and 1970 s with the advent of continuous recording instruments, the start of numerical models and the appearance of satellite remote sensing. During these years, however, physical oceanog- raphy remained largely neglected in Spain, as research on marine sciences was dominated by a long-standing tradition in biological and chemical sciences, consolidated thanks to the importance of fisheries (particularly off NW Africa) and the clear influence of the ecologist Ramon Margalef and the chemists Fernando Fraga and Antoni Ballester. In the early 1970s, Spain had no more than a handful of oceanographers studying the physical environment of the ocean (Pelegrí et al. 2012). 
This is the scenario that Jordi Font encountered in 1973. After completing a five-year undergraduate degree in physics at the Universitat de Barcelona, he obtained a scholarship to work at the Institute of Fisheries Research (Instituto de Investigaciones Pesqueras, IIP) in Barcelona, which in 1987 became the Institute of Marine Sciences (Institut de Ciències del Mar, ICM). In this biographic note we will review some of Font's main oceanographic findings as a descriptive field oceanographer who made extensive use of remote sensing techniques, but we will also recall his key leading role in the Spanish physical oceanography community, from his intuition at choosing the right directions for ocean research to his coordination of the first European mission on remote sensing of sea surface salinity (SSS). The situation in 2016 is very different from what Font found in 1973: there are now 12 permanent researchers at ICM plus some other 25 postdocs, technicians and graduate students, who are part of a Spanish community of about 100 active tenured physical oceanographers plus many more technicians and soft-money researchers.

\section{FROM NW AFRICA TO THE WESTERN MEDITERRANEAN SEA}

Font's oceanographic baptism was a two-month cruise in 1972 (Atlor I) in the upwelling region off NW Africa onboard the brand new R/V Coornide de Saavedra (first launched in 1971), still as a physics student. In 1973 Font joined the IIP to carry out the hydrographic and meteorological measurements on oceanographic cruises. His supervisor was Antoni Ballester and he was to collaborate with Jordi Salat, a mathematician, and Antonio Cruzado, a chemist, with the support of Agustí Julià and Mario Manríquez as instrument technicians. Font went back to the African region for a second cruise in 1974 (Atlor V) and eventually reported some of the sea surface distribution of properties in the region (Font 1977; Salat and Font 1977; Pastor et al. 2008), and even developed and applied a numerical model for coastal upwelling (Font and Oñoro 1985). However, the Spanish cruises off Africa ended as Morocco occupied the former Spanish Sahara in 1976, so Font's attention naturally shifted towards the Catalan Sea.

Throughout 1975 and 1976 Font participated in a series of monthly cruises off Barcelona and, in October 1976, he embarked on the first Mediterranean cruise of the R/V Coornide de Saavedra (Mediterráneo I), covering the entire eastern margin of the Iberian Peninsula and the Balearic Islands and aimed at mapping the hydrography of the region for a better understanding of its primary production. Font was in charge of the meteorology (Prego and Guerra 2003) and came out with one of the earliest descriptions of the geostrophic circulation in the Catalan Sea (Font 1978, 1983, Font and Miralles 1978)

Font's scholarship ended in early 1977 and he went into teaching mathematics at high school. For several years, he collaborated occasionally with the IIP but it was not until 1982 that he was hired again. Shortly

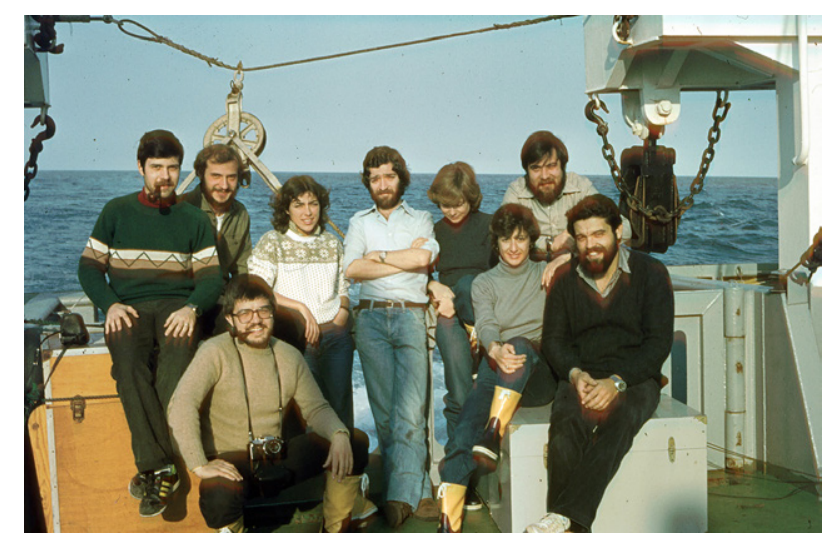

Fig. 1. - Jordi Font on board the R/V García del Cid in March 1982, during the Caron 82 cruise in the Catalan Sea. Top row, from left to right: Lluís Miralles, José Manuel Fortuño, Ana Sabatés, Xavier Fusté, Rosa Ras, Jordi Salat. Bottom row: Jordi Font, Balbina Molí, Jordi Flos.

after his reincorporation, he started a doctoral dissertation on the circulation of the Catalan Sea, under the supervision of the meteorologist Manuel Puigcerver, which he completed in 1986. In the dissertation he compiled the available information on the region, including hydrographic data from cruises carried out with the R/Vs Coornide de Saavedra, García del Cid (launched in 1979) and Vallcarca, as well as a number of scattered coastal and current meter measurements (Fig. 1). Shortly after completing the dissertation, Font obtained a permanent scientific position in physical oceanography (colaborador científico), the first position in this field ever created at any of the marine centres of the Spanish National Research Council. The IIP split into four centres in 1979, located in Barcelona, Castelló, Vigo and Cádiz, and a fifth centre was created in Blanes in 1985 (Prego and Guerra 2003).

The dissertation work, probably helped by the stability of a tenured research position, was a catalyst for a series of articles in Spanish and European proceedings and journals (Font and Ballester 1985, Salat and Font 1985, 1987, Font 1987a). This renewed vitality coincided with opportunities for collaboration with the United States, in the framework of a cooperation treaty signed in 1976, and the granting of Spanish projects to study frontal processes and mesoscale variability. One of the outcomes was the Wondering Drifters (Flotadors Errants, FE) series of cruises, with Font participating in seven $F E$ cruises between 1986 and 1992 that intensively sampled mesoscale features in the western Mediterranean (Fig. 2, left). Also in the 1980s, Font led an IIP initiative for instrumenting the Casablanca offshore oil platform, located on the shelf break off the Ebro Delta (water depth 165 $\mathrm{m}, 42 \mathrm{~km}$ from the coastline), which produced time series of oceanographic and meteorological variables that allowed an unprecedented description of the temporal variability of the Catalan Current (Font et al. 1988b, 1995, Font 1990).

The western Mediterranean cruises also marked the start of a programme of drifter observations. With the advent of satellite tracking capabilities in the 1970s and the improvements in drifter design and battery capacity 

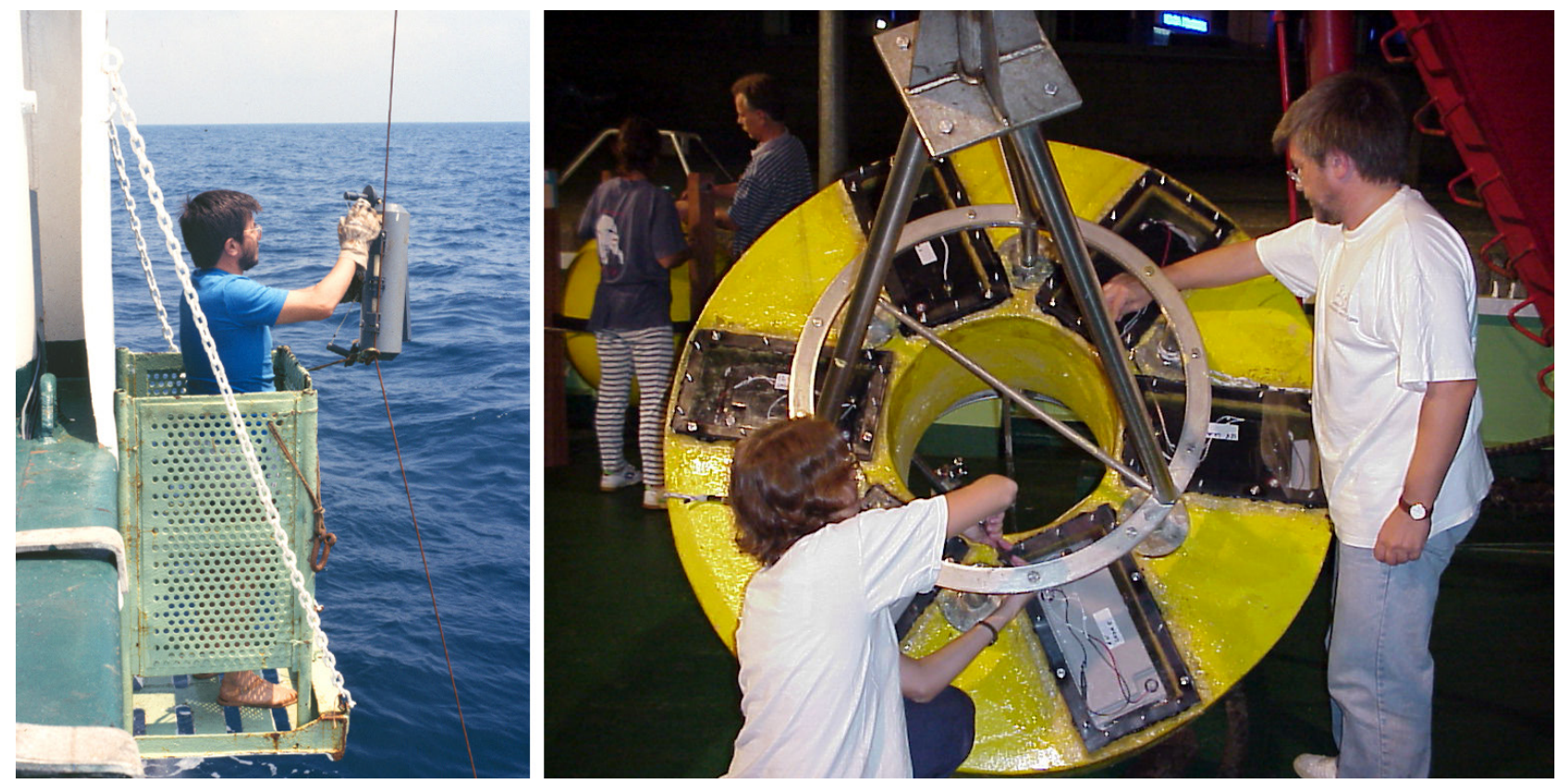

Fig. 2. - Some samples of Jordi's field work: (left panel) preparing a Niskin bottle during a Mediterranean cruise in the 1980s; (right panel) Jordi with Carolina Gabarró fine-tunning a buoy constructed at the ICM before its deployment during the WISE field experiment in 2001.

in the 1980s, drifters became a valuable tool for sampling the ocean over a wide range of scales, from tidal/ inertial to inter-annual scales and from a few to thousands of kilometres (Niiler 1995). Font played a fundamental role in launching the Lagrangian observations at the IIP in the 1980s, which have remained active during the last 30 years (García-Ladona et al. 2016). All these ongoing activities led him to supervise two doctoral thesis (Masó 1989, García-Ladona 1991; the latter co-supervised by Joaquim Tintoré) and to author numerous high-impact publications (Font 1987b, Font et al. 1988a, 1990, 1995, 1998, Castellón et al. 1990, La Violette et al. 1990, Font and Salat 1992, Salat et al. 1992, López Garcia et al. 1994, Alberola et al. 1995, García-Ladona et al. 1996, García-Górriz et al. 1997, 2003, Salas et al. 2001, 2002, Ruiz et al. 2002). The outcome of these articles was a much improved understanding of the western Mediterranean circulation at surface and intermediate water levels, with a proper recognition of the importance of mesoscale motions and the formation and spreading of intermediate and deep water masses.

Font's expertise in the western Mediterranean Sea, together with his open and persistent character and his willingness to travel and coordinate with other researchers, gave ICM the opportunity to join other European teams in concerted ventures (Send et al. 1996, 1999, Astraldi et al. 1999, Bouzinac et al. 1999, 2003). At this time Font participated in steering committees of programmes such as the Western Mediterranean Circulation Experiment (WMCE, 1988-89), the Programme de Recherches International en Méditerranée Occidentale (PRIMO, 1990-93), and the Spanish working group for the World Ocean Circulation Experiment (WOCE, 1990-93). He was also the task leader of several European Marine Science and Technology (MAST) projects, such as Hydrodynamic Modelling of the Mediterranean Western Basin (EUROMODEL 1990-95), Observations and Modelling of Eddy-Scale Geostrophic and Ageostrophic circulation (OMEGA, 1996-99), and Mass Transfer and Ecosystem Response (MATER, 1996-99).

Font became gradually more absorbed by remote sensing activities in the late 1990s, particularly through his work on satellite sensing of SSS. Nevertheless, he continued studying the circulation of the western Mediterranean (Font et al. 2004, Emelianov et al. 2006, Isern-Fontanet et al. 2006a, 2006b, 2007, Poulain et al. 2007, Ruiz et al. 2007) and also participated in the Malaspina expedition, a global sampling experiment carried out between 2008 and 2014 with R/Vs Hespérides and Sarmiento de Gamboa. Additionally, he was part of the team that in 2002 began a long-term monitoring programme of basic hydrological variables in the Mediterranean Sea, with the support of the Mediterranean Science Commission (Commission Internationale pour l'Exploration Scientifique de la mer Méditerranée, CIESM) (Font et al. 2007, Schroeder et al., 2013). Font served as Chair of the Ocean Physics and Climate Committee of the CIESM between 2004 and 2010.

\section{REMOTE SENSING OF THE OCEAN}

In 1991, Font was granted a project by the European Space Agency (ESA) to evaluate the capabilities of the microwave sensors on board the European Remote Sensing satellite ERS-1 for the study of oceanic fronts. In 1998, he was funded with another ESA project (ALGERS) that included the near-real-time analysis and transmission of ERS-2 synthetic aperture radar (SAR) data to the R/V Hespérides during an oceanographic cruise. The acquisition of these data, together with sea surface temperature (SST) data sensed through the 
Advanced Very High Resolution Radiometer scanner, allowed very good sampling of the frontal structures in the Algerian Current.

Several cruises were carried out in order to explore the potential of SAR and radar altimeter data for detecting the western Mediterranean gyres and currents, among them PRIM-1 (1992) and FE92 (1992) in the Catalan Sea, and OMEGA-1 (1996) and ALGERS (1996) in the Alboran Sea and the Algerian Basin. Drifters were deployed during these cruises, and their trajectories were examined jointly with data from hydrographic stations and velocity data obtained from the vessel-mounted acoustic Doppler current profiler (ADCP). The analysis of the SAR data and its comparison with field data gave rise to a number of papers that identified the high potential of a multi-methodological approach for the description of oceanographic phenomena (Font et al. 1993, 1996, 1998, Shirasago et al. 1994, 1995a, 1995b, 1997, Vázquez and Font 1995, Vázquez et al. 1996, Chic et al. 1997, Bouzinac et al. 1998, Rousseau and Font 2000, Rousseau et al. 2000).

This early remote sensing period was also noteworthy for Font's mentoring activity. During the 1990s he supervised a total of five doctoral theses: one on the analysis of ADCP data (García Górritz 1995; together with Julio Candela), two on SAR applications to better understand the dynamics of the Alboran Sea (Shirasago 1996, Bouzinac 1997), and two related to in situ measurements in the Alboran and western Mediterranean Seas (Salas 1999, Ruiz 2000; the latter co-supervised by Damià Gomis). In 2003, another of Font's students did his doctorate on the detection of eddies in the Mediterranean, using altimetry and other remote sensing techniques (Isern-Fontanet 2003; cosupervised by Emilio García-Ladona).

In the late 1990s, Font's interest on remote sampling led him to conduct the oceanographic part of a new ESA Earth observation satellite that was to remotely sense soil moisture and SSS (see next section). In 1999, simultaneous with these scientific and technological developments, Font and Adriano Camps (UPC) led an ESA project, the Wind and Salinity Experiment (WISE), aimed at determining the sensitivity of the L-band radiometric measurements to different oceanographic parameters, such as ocean waves, glint and sea SST (Camps et al. 2016). In the autumn of 2000 and 2001, several instruments were installed on the Casablanca platform, including a meteorological station, thermal-infrared and stereo cameras, and the Lband Automatic Radiometer (LAURA) designed and built at UPC, the first-ever fully-polarimetric L-band radiometer. Additionally, various instrumented buoys were moored near the platform (Fig. 2-right).

The WISE measurements were accompanied by a second ESA-funded project (EuroSTARRS), with Font in charge of coordinating remote and field measurements. Data was acquired with another L-band radiometer, the L-band Salinity Temperature and Roughness Remote Scanner (STARRS), carried by an airplane flying over the Casablanca platform while the WISE field measurements were taking place. The main ob- jective was to gather satellite-like observations for assessing the sensitivity of the data to different variables and parameters. Thanks to all these efforts, new L-band empirical sea surface emissivity models were developed, with dependence on wind speed/direction and wave height (Camps et al. 2004, Gabarró et al. 2004a, 2004b). Following this period, another doctoral thesis was completed under the direction of Jordi Font (Gabarró 2004; codirector Adriano Camps).

Additionally, in the framework of several projects funded by the Spanish government, a buoy was designed and constructed at the ICM in order to measure ocean temperature and salinity, either in moorings or operating as a drifter (García-Ladona et al. 2016). A version of this buoy was capable of measuring these variables at only $20 \mathrm{~cm}$ below the sea surface so, together with data from the Argo global array of profiling floats (Argo, 2016), it was to be used as the ground-truth to validate the radiometric salinity measurements (see next section). Some 100 drifters were deployed in several cruises in the Atlantic Ocean both to test SSS remote measurements and to study the trajectories and transformations of water masses. One of these experiments was a joint European-American initiative (SPURS) in the region of peak SSS in the North Atlantic, aimed at understanding the processes causing this maximum. Font was the chief scientist on board the R/V Sarmiento de Gamboa who participated in this international exercise in March 2016 (Centurioni et al. 2015, Lindstrom 2015, Reverdin et al. 2015).

Font's activities on remote sensing and surface drifters naturally led him to become involved and actively participate in international programmes on operational oceanography. During this period he was a member of the executive committee for the Marine Environment and Security for the European Area project (MERSEA, 2004-2008), the Mediterranean Operational Oceanography Network (MOON, 2004-2013) and the Hydrological cycle in the Mediterranean Experiment (HYMEX, 2008-2013), and team leader for the Mediterranean Ocean Forecasting System: Toward Environmental Predictions (MFSTEP, 2003-2006) and MERSEA (2004-2008). He was also a member of the scientific committees for the Satellite Panel Technology Plan Working Group for the European Global Ocean Observing System (1999-2001) and for both the Soil Moisture and Ocean Salinity (SMOS) and Aquarius Science Teams (2001-2016).

\section{THE SOIL MOISTURE OCEAN SALINITY MISSION}

In 1993, following the recommendations of the Advanced Microwave Radiometer Techniques Workshop held in 1991 in Copenhagen (Skou 1991), the ESA initiated a feasibility study of the Microwave Imaging Radiometer by Aperture Synthesis (MIRAS), with Matra Marconi Space (Toulouse, France) as the prime contractor. In April 1995, the ESA organized the Consultative Meeting on Soil Moisture and Ocean Salinity Measurement Requirements and Radiometer 
Techniques (Guyenne 1995), which brought together a number of international scientists and industry representatives. One of the recommendations of this meeting was that two-dimensional synthetic aperture microwave radiometry should fulfil the mapping requirements of soil moisture and ocean salinity from space, two geophysical parameters vital for climate change models. This workshop triggered a series of contracts with industry to develop some of the subsystems, which proved to be fundamental for the later success of this huge technological challenge.

This was the time of Font's early contacts with what would eventually become the first-ever satellite to measure ocean salinity from space. It was at a talk on salinity measurement from space given by Manuel Martín-Neira at the Catalan Institute of Space Studies (Institut d'Estudis Espacials de Catalunya, IEEC). Surveying the salinity globally and frequently had been for decades the holy grail of physical oceanography, and Font, as a $21^{\text {st }}$-century adventurer, perceived the opportunity of achieving it.

In November 1998, after some strategic and scientific discussions about the nature and name of the mission, a joint Earth Explorer proposal for satellite measuring of SSS (SMOS) was submitted to the ESA, led by Yann Kerr as principle investigator for soil moisture and Jordi Font as principle investigator for ocean salinity, with the support of more than 60 scientists and engineers from all over Europe (Kerr et al. 1998). In May 1999 it was announced that SMOS had been ranked second among 27 original proposals and was approved to proceed with its first phase, in which the design of the instrument was re-evaluated and the principal scientific challenges of the instrument were addressed (Silvestrin et al. 2001). The first SMOS workshop took place at the UPC in September 1999 , in what became the official start of the project. The extended industrial-activities phase kicked off officially on 13 September 2000, with Construcciones Aeronáuticas SA (CASA, Madrid, Spain) as the prime contractor of the payload. The Preliminary Concept Review took place in March 2000, focusing on the analysis of requirements, capabilities and constraints, as well as on the critical review of previous developments and the elaboration of instrument configurations and mission profiles.

We have to admit that, although it was clear that SMOS could measure the soil moisture signal, it was not evident at all that it could sense the much weaker SSS signature... at least with the knowledge we had in 1999. Ten years of work were lying ahead to prepare for this task (Fig. 3) (Font et al. 2010). SMOS was going to be an orbiting radio-telescope looking down to Earth, resembling the Very Large Array (VLA) in the National Radio Astronomy Observatory in Socorro, New Mexico (United States) (NRAO 2016). This may have appeared an easy challenge, as many of the techniques used in the VLA could be exported from radio astronomy into SMOS, but it actually turned to be much more complicated. The many problems to solve had been anticipated early (Camps 1996): tens of antennas very close to each other, not close enough to

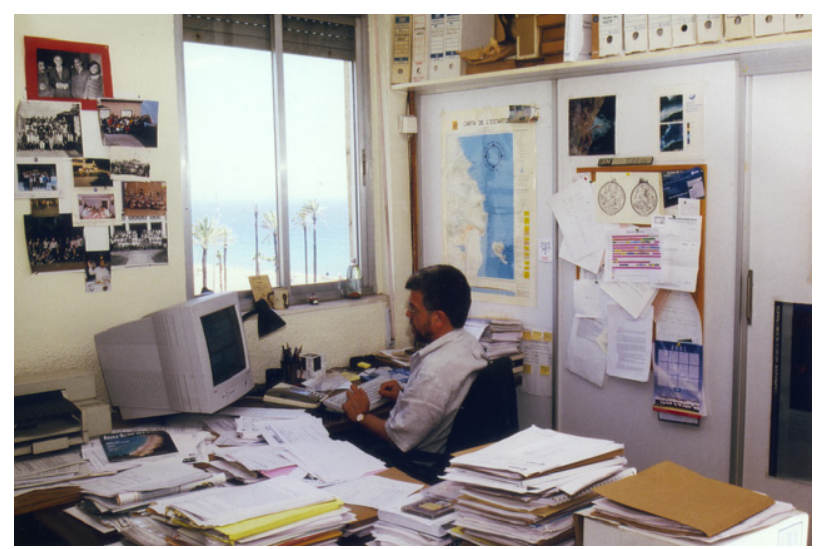

Fig. 3. - Jordi Font at his office in the original ICM building in 2001

provide an entire alias-free field of view but sufficiently near to induce significant mutual coupling effects that would distort the antenna pattern and hinder the calibration and image reconstruction algorithms; thousands of complex correlators processing in real time all the signals collected by the 69 antenna elements in an array with millimetre coplanarity requirements; and optical harness never used before in space to bring the signals from all receivers to the satellite hub where the correlator matrix was located. It all appeared an impossible mission but the hard work of many people, led by excellent scientists and team leaders such as Font, would make it possible.

On 24 September 2003, the Programme Board for Earth Observation of ESA unanimously approved SMOS to continue to the development phase, which allowed the MIRAS instrument to be built and tested (SMOS 2003). To carry out this phase it was necessary to have full support from the Spanish Research programmes. Font, with his savoir faire and hard and constant work, secured this support between 2001 and 2012 through a series of six MIDAS research projects, initially within the ICM (the scientific branch) and afterwards joining forces with the UPC (the engineering branch). On 25 July 2007, during the International Geoscience and Remote Sensing Symposium held in Barcelona, the SMOS Barcelona Expert Centre (BEC) was officially inaugurated as a joint ICM-UPC in order to optimize the collaboration between the two teams (SMOS 2007, Turiel et al. 2016).

Everything was ready... and finally, on 2 November 2009, SMOS was launched from the Plesetsk Cosmodrome in Russia (Fig. 4-right) (SMOS 2009). Font went to the European Space Astronomy Centre near Madrid to follow the launching and attend the official celebration of the event (Fig. 4, left) but the team remained at the ICM premises waiting for the first contact with the satellite to celebrate that, 17 years after the first studies on aperture synthesis radiometers and 11 years after the first proposal submission, the dream had come true!

After SMOS went into orbit, a very tough and stressful period started at the BEC with the commissioning phase, aimed at setting the instrument into full operational mode (Martín-Neira et al. 2010, Sabia et al. 

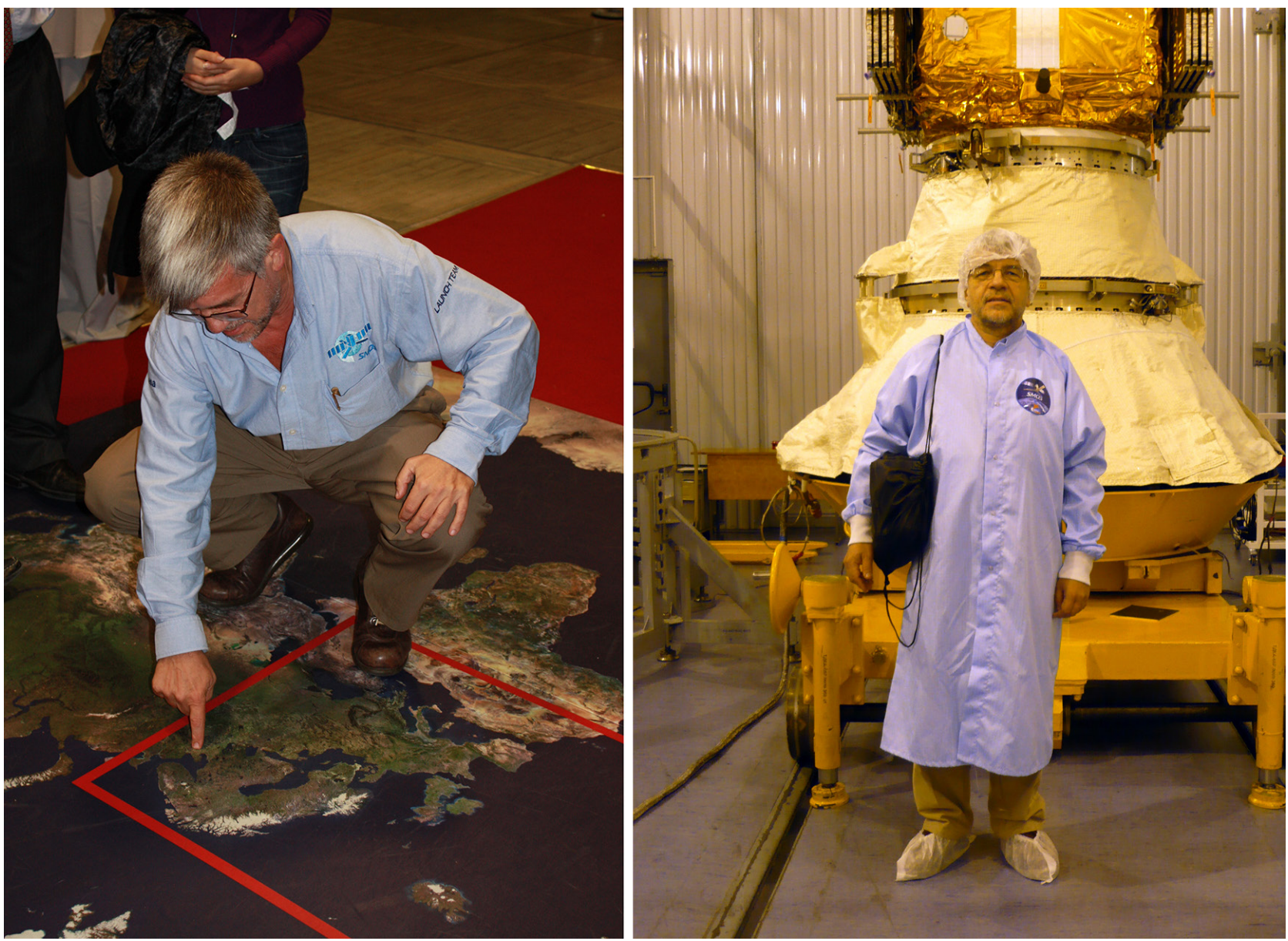

Fig. 4. - (Left panel) Jordi Font during a press event in Barcelona in November 2009, a few days before launching the SMOS. (Right panel) Jordi with the ROCKOT behind, carrying the SMOS satellite, ready to be launched at Plesetsk, in northern Russia, in 2009.

2010). We soon realized that many problems were yet to be solved: radio frequency interferences from many unexpected sites, much more severe than the most pessimistic estimations (Oliva et al. 2012 DaganzoEusebio et al. 2013); mismatch in the phase definition of the antennas-when will engineers and physicists agree on the signs of arguments in exponentials like like exp(iwt) and $\exp (-\mathrm{ikr})$ ?; scene-dependent biases; correlators' offsets; subsystem failures and turn-on of redundant subsystems; problems with the local oscillator, with its phase-locked loop as SMOS passed over the spacecraft Bermuda triangle; the adjustment of the non-separable amplitude terms; and flat target transformations. Solving all these issues, one at a time, involved many hours of hard work, squeezing our neurons to understand what was happening.

Six months after launching, the results of the commissioning phase were reviewed (SMOS 2010) and SMOS went into the operational phase, in which data started to be delivered to the international community. During this phase, the hard work has always remained, with continuous algorithm improvements, new reprocessing campaigns, data validation and delivery, and a great effort dedicated to fostering the international use of data. Though we still do not completely understand all issues, there has been an enormous improvement, to the point that we can now determine soil moisture at 500-m resolution (a 100 factor improvement from the original expectations!) and we can also obtain SSS up to a few hundreds of kilometres from the coast (allowing the Mediterranean Sea and Arctic Ocean to be mapped) and even sense the ice thickness. Further, we have combined land and ocean analyses, finding teleconnections between soil moisture and salinity changes all over the world (Kouraev et al. 2010, Hackert et al. 2011). All this work has resulted in many scientific and engineering results, summarized in the reviews by Camps et al. (2016) and Turiel et al. (2016).

\section{JORDI FONT: EXCELLENCE IN SCIENCE AND COMPANIONSHIP}

Font has been instrumental in getting physical oceanography fully recognized in Spain as a research field in its own right. He has promoted a discipline that was marginal in Spanish marine sciences 40 years ago, transmitting the message that the marine system cannot be studied without a proper understanding of the physical environment. The sustained progress of the Physical and Technological Oceanography Department at the ICM (DOFT) is possibly the best example of his vital commitment: he has used all his efforts and expertise for the growth of a cross-cutting and highly interdisciplinary group, and he has definitely succeeded (Fig. 5) (DOFT 2016a). 


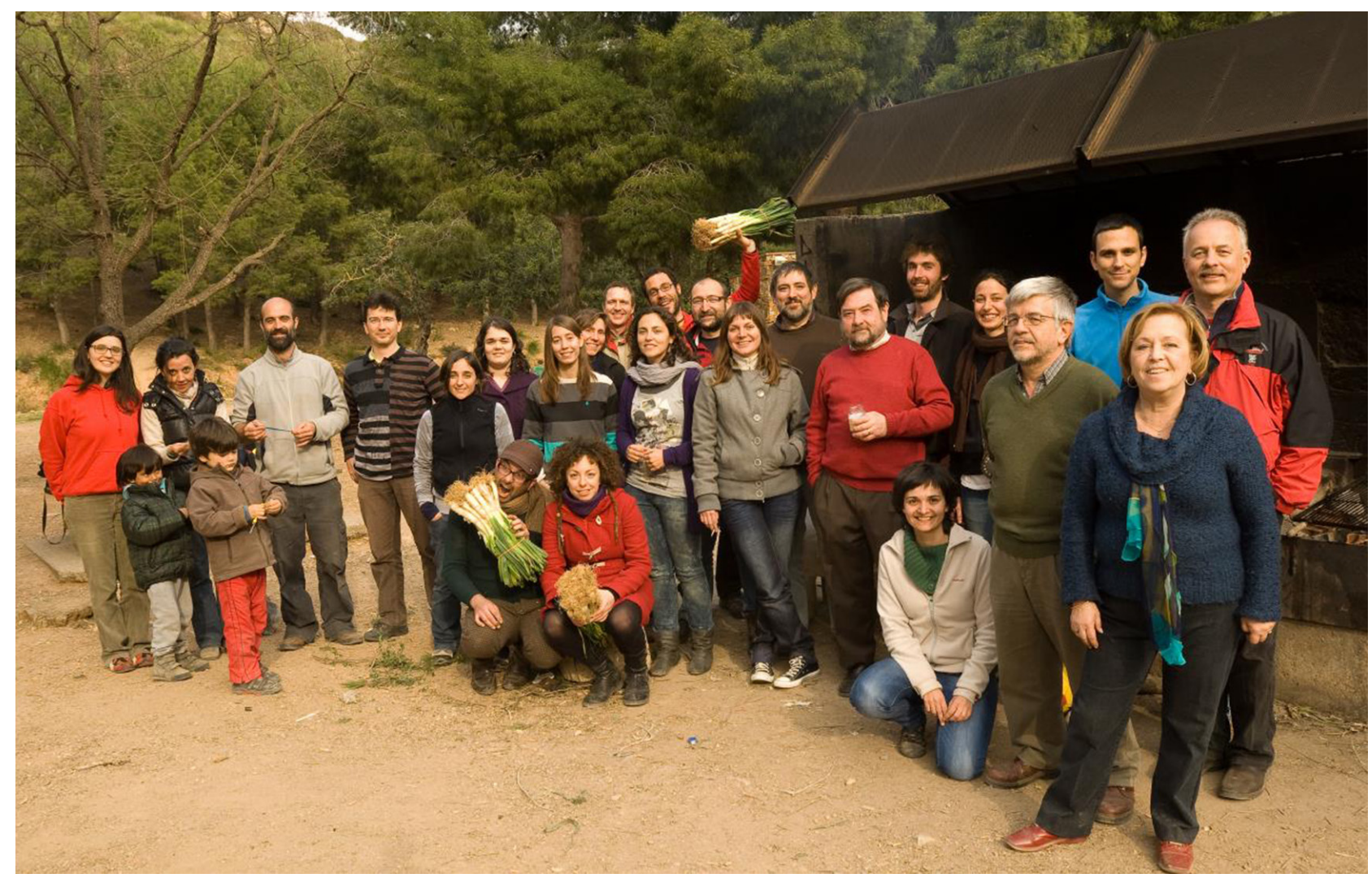

Fig. 5. - A social gathering of members of the Department of Physical and Technological Oceanography in 2011. These meetings were regularly organized by Jordi Font and Maria Rosa Vitrià (bottom right of the picture).

Jordi Font is Research Professor of the National Research Council. He has published some 300 papers, with about one-third in SCI journals (an h-index of 32 according to the Web of Science and 38 according to Scopus). A complete list of Font's publications is accessible at DOFT (2016b) and a collection of most of these publications, together with several essays on his career and legacy, is available at DOFT (2016c). In 2011, the Catalan government (Generalitat de Catalunya) recognized his career by granting him the national Art Prize in the category of Scientific Thought and Culture (Fig. 6). The SMOS project also received the Cristòfol Juandó Award from the City Council of Barcelona, the Certificates of Recognition of the IEEE Geosciences and Remote Sensing Society, and the ESA Award for Corporate Team Achievement.

This brief note is no more than a small token of gratitude to Jordi Font from the entire DOFT as well as from many collaborators at the UPC and elsewhere. Over and above his intelligence, hard work, perseverance and scientific leadership, Jordi has always been a friendly companion and teacher, an example of reflection and action, gentleness and tenacity. We cannot think of a better team-oriented researcher, somebody to trust and ask for advice, the steady rock to hold onto in troubled waters: indeed, he is the serene oceanographer.

\section{REFERENCES}

Alberola C., Millot C., Font J. 1995. On the seasonal and mesoscale variabilities of the Northern Current during the PRIMO-0 in the western Mediterranean Sea. Oceanol. Acta. 18: 163-192.

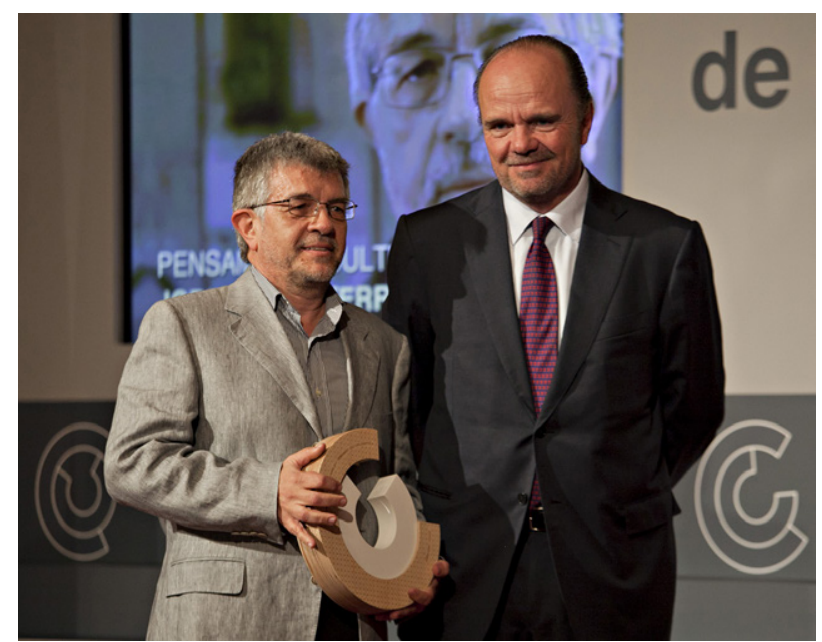

Fig. 6. - In 2011 Jordi Font received the National Arts Award on Scientific Thought and Culture. The photo shows Font after receiving the prize from Francesc Guardans, former president of the National Council of Arts and Culture of the Catalan government (Foto $\odot$ Cazurro).

Argo. 2016. http://www.argo.net/. Last accessed 30 June 2016.

Astraldi M., Balopoulos S., Candela J., et al. 1999. The role of straits and channels in understanding the characteristics of Mediterranean circulation. Progr. Oceanogr. 44: 65-108. http://dx.doi.org/10.1016/S0079-6611(99)00021-X

Bouzinac C. 1997. Variabilité spatiale et temporelle de la circulation superficielle dans la región du Courrant Algerien. Doctoral dissertation, Universite Pierre et Marie Curie.

Bouzinac C., Font J., Millot C. 1999. Hydrology and currents observed in the channel of Sardinia during the PRIMO-1 experiment from November 1993 to October 1994. J. Mar. Syst. 20: 333-355. 
http://dx.doi.org/10.1016/S0924-7963(98)00074-8

Bouzinac C., Vázquez J., Font J. 1998. CEOF analysis of ERS-1 and Topex/Poseidon combined altimetric data in the region of the Algerian current. J. Geophys. Res. 103: 8059-8071. http://dx doi.org/10.1029/97JC02909

Bouzinac C., Font J., Johannessen J. 2003. Annual cycles of sea level and sea surface temperature in the western Mediterranean Sea. J. Geophys. Res. 108: 3059. http://dx.doi.org/10.1029/2002JC001365

Camps A. 1996. Application of Interferometric Radiometry to Earth Observation. Doctoral dissertation, Universitat Politècnica de Catalunya.

Camps A., Font J., Vall-llossera M., et al. 2004. The WISE 2000 and 2001 campaigns in support of the SMOS Mission: Sea surface L-band brightness temperature observations and their application to multi-angular salinity retrieval. IEEE Trans. Geosci. Remote Sens. 42: 804-823. http://dx.doi.org/10.1109/TGRS.2003.819444

Camps A., Gabarró C., Vall-llossera M., et al. 2016. From field experiments to salinity products: a tribute to the contributions of Jordi Font to the SMOS mission. Sci. Mar. 80S1: 159-172. http://dx.doi.org/10.3989/scimar.04285.04A

Castellón A., Font J., García-Ladona E. 1990. The Liguro-Provençal-Catalan current (NW Mediterranean) observed by Doppler profiling in the Balearic Sea. Sci. Mar. 54: 269-276.

Centurioni L.R., Hormann V., Chao Y., et al. 2015. Sea surface salinity observations with Lagrangian drifters in the tropical North Atlantic during SPURS: Circulation, fluxes, and comparisons with remotely sensed salinity from Aquarius. Oceanogr. 28: 96-105. http://dx.doi.org/10.5670/oceanog.2015.08

Chic O., Font J., Sandven S. 1997. ERS-2 SAR near real time data used in the sampling strategy of an oceanographic cruise in the western Mediterranean. In: Guyenne T.D., Danesy D. (eds), Space at the Service of our Environment. 3rd ERS-1 Symposium, ESA SP-414: 1433-1438, ISBN-92-9092-656-2.

Daganzo-Eusebio D., Oliva R., Kerr Y.H., et al. 2013. SMOS radiometer in the 1400-1427-MHz passive band: impact of the RFI environment and approach to its mitigation and cancellation. IEEE Trans. Geosci. Remote Sens. 51: 4999-5007. http://dx.doi.org/10.1109/TGRS.2013.2259179

DOFT. 2016a. History, Department of Physical and Technological Oceanography, ICM. http://oce.icm.csic.es/en/history. Last accessed 15 July 2016.

DOFT. 2016b. Collecciones del Departamento de Oceanografía Física y Tecnológica. http://oce.icm.csic.es/es/colecciones. Last accessed 15 July 2016.

DOFT. 2016c. Jordi Font. http://oce.icm.csic.es/ca/jfont. Last accessed 15 July 2016.

Emelianov M., Font J., Turiel A., et al. 2006. Transformation of Levantine Intermediate Water tracked by MEDARGO floats in the Western Mediterranean. Ocean Sci. 2: 281-290. http://dx.doi.org/10.5194/os-2-281-2006

Font J. 1977. Distribución superficial de variables oceanográficas en el NO de Africa Res. Exp. Cient. B/O Cornide 6: 23-40.

Font J. 1978. Courants généraux dans la mer Catalane en automne. IV Journées Etud. Pollutions, CIESM, pp. 559-562.

Font J. 1983. Corrientes permanentes en el borde de la plataforma continental frente al Delta del Ebro. In: Castellví J. (ed), Estudio Oceanografíco de la Plataforma Continental (EOPC), Resultados del Proyecto 793020 Comité Conjunto HispanoNorteamericano, Vol. I., ICM-CSIC, pp. 149-161.

Font, J. 1987a. Nuevos aspectos del estudio de la circulación marina en el Mediterráneo noroccidental. Inf. Tecn. Inv. Pesq. 141: 3-28.

Font J. 1987b. The path of the Levantine Intermediate Water to the Alboran Sea. Deep-Sea Res. I. 34: 1745-1755. http://dx.doi.org/10.1016/0198-0149(87)90022-7

Font J. 1990. A comparison of seasonal winds with currents on the continental slope of the Catalan Sea (NW Mediterranean). J. Geophys. Res. 95: 1587-1545. http://dx.doi.org/10.1029/JC095iC02p01537

Font J., Ballester A. 1985. Seasonal velocity variations in the continental side of the Catalan Gyre. Rapp. Comm. int. Mer Médit. 29: 105-106.

Font J., Miralles L. 1978. Circulación geostrófica en el Mar Catalán. Res. Exp. Cient. B/O Cornide 7: 155-163.

Font J., Oñoro A. 1985. Modelo tridimensional de simulación de la circulación sobre la plataforma continental frente a Cabo Bojador (Costa sahariana). Inv. Pesq. 49: 97-105.
Font J., Salat J. 1992. The Balearic Basin. In: Charnock H. (ed), Winds and Currents of the Mediterranean Basin. Rep. Meteorol. Oceanogr. Harvard University 40, pp. 225-240.

Font J. and Algers group. 1998. ALGERS'96 Cruise, October 1996: an interdisciplinary study of a mesoscale instability of the Algerian current (Western Mediterranean Sea). Rapp. Comm. int. Mer Médit. 35: 1998.

Font J., Camps A., Borges A., et al. 2010. SMOS: The challenging sea surface salinity measurement from space. Proc. IEEE 98: 649-665. http://dx.doi.org/10.1109/JPROC.2009.2033096

Font J., García-Ladona E., García Górriz E. 1995. The seasonality of mesoscale motion in the Northern Current of the western Mediterranean: several years of evidence. Oceanol. Acta 18: 207-219

Font J., Isern-Fontanet J., Salas J.J. 2004. Tracking a big anticyclonic eddy in the western Mediterranean Sea. Sci. Mar. 68: 331-342. http://dx.doi.org/10.3989/scimar.2004.68n3331

Font J., Martínez A., García-G E., et al. 1993. Comparison of ERS-1 SAR images of the Western Mediterranean to in situ oceanographic data: PRIM-1 cruise (May 1992). In: Kaldeich B. (ed), Space at the Service of our Environment. First ERS-1 Symposium, ESA SP-359, Noordwijk: 883-887, ISBN 92-0092-278-8.

Font J., Millot C., Salas J., et al. 1998. The drift of modified Atlantic water from the Alboran sea to the eastern Mediterranean. Sci. Mar. 62: 211-216. http://dx.doi.org/10.3989/scimar.1998.62n3211

Font J., Puig P., Salat J., et al. 2007. Sequence of hydrographic changes in NW Mediterranean deep water due to the exceptional winter of 2005. Sci. Mar. 71: 339-346. http://dx.doi.org/10.3989/scimar.2007.71n2339

Font J., Salat J., Julià A. 1990. Marine circulation along the Ebro continental margin. Mar. Geol. 95: 165-177. http://dx.doi.org/10.1016/0025-3227(90)90114-Y

Font J., Salat, J., Tintoré J. 1988a. Permanent features of the circulation in the Catalan Sea. Oceanol. Acta 9: 51-57.

Font J., Salat J., Wang D.P. 1988b. Lagrangian and Eulerian observation of inertial oscillations in the shelf break offshore the Ebro River Delta (Catalan Sea, NW Mediterranean). Rapports et Proces-verbaux des Réunions. Com. Int. Explor. Sci. Mer Mediterranée CIESM 31: 2.

Font J., Shirasago B., Martínez J.J., et al. 1996. Evaluation of ERS1 microwave sensors capability in the study of oceanic fronts. Rev. Teledet. 6: 27-36.

Gabarro C. 2004. Study of salinity retrieval errors for the SMOS mission. Doctoral dissertation, Universitat Politècnica de Catalunya.

Gabarró C., Font J., Camps A., et al. 2004a. A new empirical model of the sea surface microwave emissivity for the salinity remote sensing. Geophys. Res. Lett. 31: L01309. http://dx.doi.org/10.1029/2003GL018964

Gabarró C., Font J., Camps A., Vall-1lossera M. 2004b. Determination of Sea Surface Salinity and Wind speed by L-band Radiometry from a fixed platform. Int. J. Remote Sens. 25: 111-128. http://dx.doi.org/10.1080/0143116031000115175

García-Ladona E. 1991. Estudio numérico de la dinámica de la capa superficial oceánica: apliación al Mar Catalán. Doctoral dissertation, Universitat Autònoma de Barcelona.

García-Ladona E., Castellón A., Font J., Tintoré J. 1996. The Balearic current and volume transports in the Balearic basin. Oceanol. Acta. 19: 489-497.

García-Ladona E., Salvador J., Fernandez P., et al. 2016. Thirty years of research and development of Lagrangian buoys at the Institute of Marine Sciences. Sci. Mar. 80S1: 143-160. http://dx.doi.org/10.3989/scimar.04325.14A

García-Górriz E. 1995. Aplicación de un perfilador acústico por efecto Doppler a la medida de corrientes marinas en el Mediterráneo Occidental. Doctoral dissertation, Universitat Politècnica de Catalunya.

García-Górriz E., Candela J., Font J. 2003. Near-inertial and tidal currents detected with a vessel mounted acoustic Doppler current profiler in the western Mediterranean Sea. J. Geophys. Res. 108: 3164. http://dx.doi.org/10.1029/2001JC001239

García-Górriz E., Font J., Candela J. 1997. Data quality control for vessel mounted acoustic doppler current profiler. Application for the Western Mediterranean Sea. Sci. Mar. 61: 417-430.

Guyenne T.F. 1995. Proceedings of the Consultative Meeting on Soil Moisture and Ocean Salinity Measurement Requirements 
and Radiometer Techniques, SMOS-ESTEC. European Space Agency WPP, Vol 87, Noordwijk, The Netherlands, 20-21 April 1995.

Hackert E., Ballabrera-Poy J., Busalacchi A.J., et al. 2011. Impact of sea surface salinity assimilation on coupled forecasts in the tropical Pacific. J. Geophys. Res. 116: C05009. http://dx.doi.org/10.1029/2010JC006708

Isern-Fontanet J. 2003. Estadística de vortex coherents a la Mediterrània: Anàlisi de la superfície lliure del mar. Doctoral dissertation, Universitat Politècnica de Catalunya.

Isern-Fontanet J., García-Ladona E., Font J. 2006a. Vortices of the Mediterranean Sea: an altimetric perspective. J. Phys. Oceanogr. 36: 87-103. http://dx.doi.org/10.1175/JPO2826.1

Isern-Fontanet J., García-Ladona, E., Font J., García-Olivares A. 2006b. Non-Gaussian velocity probability density functions: An altimetric perspective of the Mediterranean Sea. J. Phys. Oceanogr. 36: 2153-2164. http://dx.doi.org/10.1175/JPO2971.1

Isern-Fontanet J., Turiel A., García-Ladona E., Font J. 2007. Microcanonical multifractal formalism: Application to the estimation of ocean surface velocities. J. Geophys. Res. 112: C05024. http://dx.doi.org/10.1029/2006JC003878

Kerr Y.H., et al. 1998. SMOS (MIRAS on RAMSES). Proposal in answer to the Call for Earth Explorer Opportunity Missions (Reference: COP 16), November 30th, 1998.

Kouraev A., et al. 2010. From wet to arid zones: continental hydrology from satellite multi-sensor data and in situ observations. https://earth.esa.int/workshops/livingplanetsymposium2010/sessions/CXNL_10a04 872827.html. Last accessed 30 July 2016.

La Violette P.E., Tintoré J, Font J. 1990. The surface circulation of the Balearic Sea. J. Geophys. Res. 95: 1559-1568. http://dx.doi.org/10.1029/JC095iC02p01559

Lindstrom E., Bryan F., Schmitt R. 2015. SPURS: Salinity processes in the upper-ocean regional study - The North Atlantic Experiment. Oceanogr. 28:14-19 http://dx.doi.org/10.5670/oceanog.2015.01

López García M.J., Millot C., Font J., García-Ladona E. 1994. Surface circulation variability in the Balearic Basin. J. Geophys. Res. 99: 3285 - 3296. http://dx.doi.org/10.1029/93JC02114

Martín-Neira M., Corbella I., Torres F., et al. 2010. SMOS payload performance assessment. Proceedings of the Geoscience and Remote Sensing Symposium (IGARSS), 2010 IEEE International, Honolulu, HI, 2010, pp. 3150-3153. http://dx.doi.org/10.1109/IGARSS.2010.5649704

Masó M. 1989. Variabilidad espacio-temporal de las características oceanográficas de la zona costera y su relación con el sistema planctónico. Doctoral dissertation, Universitat de Barcelona.

Niiler P.P. 1995. Measurements of the water-following capability of holey-sock and TRISTAR drifters. Deep Sea Res. I 42: 1951-1964. http://dx.doi.org/10.1016/0967-0637(95)00076-3

NRAO. 2016. National Radio Astronomy Laboratory. http://www. aoc.nrao.edu/. Last accessed 30 June 2016.

Oliva O., Daganzo E., Kerr Y.H., Mecklenburg S., Nieto S., Richaume P., Gruhier C. 2012. SMOS radio frequency interference scenario: status and actions taken to improve the RFI environment in the $1400-1427-\mathrm{MHz}$ passive band. IEEE Trans. Geosci. Remote Sens. 50: 1427-1439. http://dx.doi.org/10.1109/TGRS.2012.2182775

Pastor M.V., Pelegrí J.L., Hernández-Guerra A., et al. 2008. Water and nutrient fluxes off Northwest Africa. Cont. Shelf Res. 28: 915-936. http://dx.doi.org/10.1016/j.csr.2008.01.011

Pelegrí J.L., Álvarez-Fanjul E., Espino M., et al. 2012. Crucial times for the Spanish Physical Oceanography community. Sci. Mar. 76S1: 11-28.

Poulain P.M., Barbanti R., Font J., et al. 2007. MedArgo: a drifting profiler program in the Mediterranean Sea. Ocean Sci. 3: 379-395. http://dx.doi.org/10.5194/os-3-379-2007

Prego R., Guerra A. 2003. El Instituto de Investigaciones Pesqueras - Tres Dècades de Historia de la Investigación Marina Española. Ediciones CSIC, Madrid, 344 pp.

Reverdin G., Morisset S., Marié L., et al. 2015. Surface salinity in the North Atlantic subtropical gyre during the STRASSE/ SPURS summer 2012 cruise. Oceanogr. 28: 114-123. http://dx.doi.org/10.5670/oceanog.2015.09

Rousseau S., Font J. 2000. Detección por radar del frente del giro occidental del Mar de Alborán. In: $2^{\text {a }}$ Asamblea Hispano-Portuguesa de Geodesia y Geofísica. Instituto Geofísico Infante D. Luis (IGIDL), pp 565-566.

Rousseau S., García-Górriz E., Font J., et al. 2000. Detection by ERS SAR imagery of the Western Alborán gire frontal structure (Western Mediterranean) during the OMEGA-1 and FE92 cruises. In: Proceedings VI International Conference on Remote Sensing for Marine and Coastal Environments, Charleston SC, pp. II 31-38.

Ruiz S. 2000. Análisis espacial objetivo de datos oceanográficos: aplicaciones en el Mar de Alborán. Doctoral dissertation, Universitat Politècnica de Catalunya.

Ruiz S., Font J., Emelianov M., et al. 2002. Deep structure of an open sea eddy in the Algerian Basin. J. Mar. Syst. 33-34: 179-195. http://dx.doi.org/10.1016/S0924-7963(02)00058-1

Ruiz S., Gomis D., Font J. 2007 Recovery of North-East Atlantic temperature fields from profiling floats: Determination of the optimal float number from sampling and instrumental error analysis. J. Mar. Syst. 65: 212-223. http://dx.doi.org/10.1016/j.jmarsys.2005.04.012

Sabia R., Gourrion J., Portabella M., et al. 2010. SMOS measurements preliminary validation against modeled brightness temperatures and external-source salinity data. Proceedings of the Geoscience and Remote Sensing Symposium (IGARSS), 2010 IEEE International, Honolulu, HI, 2010, pp. 3166-3169, doi: 10.1109/IGARSS.2010.5651336. http://dx.doi.org/10.1109/IGARSS.2010.5651336

Salas J. 1999. Estudio Lagrangeano de la circulación superficial en la Cuenca Argelina (Mar Mediterráneo Occidental). Doctoral dissertation, Universitat Politècnica de Catalunya.

Salas J., García-Ladona E., Font J. 2001. Statistical analysis of the surface circulation in the Algerian Current using Lagrangian buoys. J. Mar. Syst. 29: 69-85. http://dx.doi.org/10.1016/S0924-7963(01)00010-0

Salas J., Millot C., Font J., García-Ladona E. 2002. Analysis of mesoscale phenomena in the Algerian Basin observed with drifting buoys and infrared images. Deep-Sea Res. 49: 245-266. http://dx.doi.org/10.1016/S0967-0637(01)00052-8

Salat J., Tintoré J., Font J., et al. 1992. Near-inertial motion on the shelf-slope front off northeast Spain. J. Geophys. Res. 97: 7277-7281. http://dx.doi.org/10.1029/92JC00588

Salat J, Font J. 1977. Internal waves in the NW African upwelling. In: Nihoul J.C.J. (ed), Bottom Turbulence. Proceedings of the 8th International Liege Colloquium on Ocean Hydrodynamics. Elsevier Oceanography Series 19, pp. 269-273.

Salat J., Font J. 1985. Masses d'aigua i circulació. In: J. Flos (ed), L'Oceanografia. Introducció a l'ecologia marina mediterrània. Quad. Ecol. Aplicada, 8: 61-98.

Salat J., Font J. 1987. Water mass structure near and offshore the Catalan coast during the winters of 1982 and 1983. Ann. Geophys. 5B: 49-54.

Schroeder K et al. 2013. Long-term monitoring programme of the hydrological variability in the Mediterranean Sea: a first overview of the HYDROCHANGES network. Ocean Sci. 9: 301-324. http://dx.doi.org/10.5194/os-9-301-2013

Send U., Font J., Mertens C. 1996. Recent observation indicates convection's role in deep water circulation. Eos Trans. Amer. Geophys. Union AGU 77: 61-65. http://dx.doi.org/10.1029/96EO00040

Send U., Font J., Krahmann G., et al. 1999. Recent advances in observing the physical oceanography of the western Mediterranean Sea. Progr. Oceanogr. 44: 37-64. http://dx.doi.org/10.1016/S0079-6611(99)00020-8

Shirasago B. 1996. Aplicaciones del radar de apertura sintética (SAR) del satélite ERS-1 al estudio de la dinámica superficial de mesoescala en el Mediterráneo Occidental. Doctoral dissertation, Universitat de Barcelona.

Shirasago B., García-Górriz E., Font J. 1994. Comparison between ERS-1 SAR images and acoustic Doppler current profiler (ADCP) velocity data in the Alboran Sea. In: Johanessen J.A., Guymer T.H. (eds), Oceanic Remote Sensing and Sea Ice Monitoring. Society of Photo-Optical Instrumentation Engineers, Bellingham, Europto Series, 2319: 165-172.

Shirasago B., García Górriz E., Font J. 1995a. Observation of mesoscale structures in the Alboran sea with ERS-1 SAR images and data from acoustic Doppler current profiler (ADCP) and CTD. Rapp. Comm. Int. Mer Médit. 34: 195.

Shirasago B., García Górriz E., Font J. 1995b. Detección de estruc- 
turas de mesoescala en el Mediterráneo occidental mediante imágenes SAR del ERS-1 y datos oceanográficos. In: VI Reu. Cient. Asoci. Esp. Teledet., pp. 38-39.

Shirasago B., García-Górriz E., Font J. 1997. Detección de estructuras de mesoescala en el Mediterráneo occidental mediante imágenes SAR del ERS-1 y datos oceanográficos. In: Teledetección: usos y aplicaciones: 101-108, ISBN: 84-7762-693-6.

Silvestrin P., Berger M., Kerr Y., Font J. 2001. ESA's second Earth Explorer Opportunity Mission: The soil moisture and ocean salinity observations. IEEE Trans. Geosci. Rem. Sens. Newsletter 118: 11-14.

Skou N. 1991. Final Report of ESTEC Contract No.8968/90/NL/ US(SC). Workshop on Advanced Microwave Radiometric Techniques, vol. 3 of 3, R 476, August 1991

SMOS. 2003. SMOS apporved to move into next phase of development. http://www.esa.int/Our_Activities/Observing_the_Earth/ SMOS/SMOS_approved_to_move_into_next_phase_of_development. Last accessed 30 July 2016.

SMOS. 2007. SMOS BEC inauguration during IGARSS 2007. http://www.smos-bec.icm.csic.es/inauguration_of_the_smos_ bec. Last accessed 30 July 2016.
SMOS. 2009. SMOS launched together with PROBA-2 in November 2009 using the Rockot launch vehicle from Plesetsk Cosmodrome in Northern Russia. http://www.eurockot.com/missions/ launch-record/smos-proba-2/. Last accessed 30 July 2016.

SMOS. 2010. SMOS team reviews results of the mission's commissioning phase in Avila. http://www.esa.int/spaceinimages/ Images/2010/05/SMOS_team_in_Avila. Last accessed 30 July 2016

Turiel A., Piles M., González-Gambau V., et al. 2016. 2000 days of SMOS at the Barcelona Expert Centre: a tribute to the work of Jordi Font. Sci. Mar. 80S1: 173-193. http://dx.doi.org/10.3989/scimar.04291.15A

Vázquez J., Font J. 1995. Long term temporal evolution of the surface layer circulation in the Alboran sea observed from the ERS-1 altimeter. Rapp. Comm. int. Mer Médit. 34: 1998.

Vázquez J., Font J., Martínez-Benjamín J.J. 1996. Observations on the circulation in the Alboran Sea using ERS1 Altimetry and Sea Surface Temperature data. J. Phys. Oceanogr. 26: 1426-1439. http://dx.doi.org/10.1175/1520-0485(1996)026<1426:OOTCIT $>2.0 . \mathrm{CO} ; 2$ 